\title{
Islam at Jesuit Colleges and Universities
}

\author{
Aysha Hidayatullah and Erin Brigham, editors \\ San Francisco, CA: University of San Francisco Press, 2016 \\ (74 pages, ISBN 978-1944769130, \$12.95)
}

\author{
Reviewed By \\ Joshua Canzona \\ Wake Forest University \\ School of Divinity
}

\begin{abstract}
The product of a 2015 conference on "Islam at U.S. Jesuit Colleges and Universities," this slim volume collects the written remarks of seven participants. In her introduction, Aysha Hidayatullah reveals two of the questions which inspired the event: (1) How did her Islamic studies colleagues at other Jesuit schools view their work in relation to the Jesuit mission of those institutions, and (2) How is the growing engagement with Islam and Muslims impacting Jesuit schools broadly? Speaking to these questions and dozens more, this book will prove a useful touchstone for future conversation concerning its title themes.
\end{abstract}

In an essay on Jesuit history, mission, and identity, John Borelli describes what he calls "the Ignatian charism for dialogue," particularly interreligious dialogue informed by Nostra Aetate and The 34th General Congregation of the Society of Jesus (19). This pairs well with Paul Shore's paper offering "snapshots" from the historical journey of Muslim-Jesuit relations. Citing Pierre Teilhard de Chardin and Ibn Rushd, Shore suggests the relationship between science and belief can be a fruitful starting point for conversation between Christians and Muslims.

In his chapter, Patrick Ryan, SJ describes his efforts to promote dialogue and mutual understanding among Muslims, Jews, and Christians at Fordham University and the piece pairs well with Isra Yazicioglu's reflections on teaching Islamic studies for six years at Saint Joseph's University. She expresses her belief in the transformative power of religion and the "immense need for talking about religion in a meaningful way" (29). She contends that the creation of a collaborative atmosphere for this kind of conversation among Muslims and Christians is part of the promise of Jesuit universities.

Martin Nguyen offers a broad essay considering how Muslims might be able to do constructive theology at a Jesuit university, the challenges of teaching about Islam in a post-9/11 world, and the type of classroom activities that foster deeper thinking about Islam and Muslim experience. With respect to the last theme, he describes two engaging activities: one where students design a mosque and another where they must memorize Al-Fätihah, the opening chapter or sürah of the Qur'an.

Thomas Michel, SJ provides a hopeful essay on the common mission of Christians and Muslims in the modern world as brothers and sisters “joined by God for God's own purpose." He writes, "That purpose is that we Muslims and Christians bear witness together, in our very secular and often self-centered society, to the values that come from God's word . . compassion, hope, generosity, mercy, and reconciliation in a world that often scoffs at such principles" (57). In the closing chapter on "The Future of Islam at Jesuit Universities," Amir Hussain strikes a similar tone with an appeal to the "language of love." He makes a timely plea, "As Catholics and Muslims, we need to stand with each other ... to speak out when those in your community malign us, just as we must speak out when those in our community malign you" (70). And this captures much of the spirit of the book as a whole. The reader emerges with a sense that there is much important work to be done in service to a future where Muslims and Christians can be better prepared to have meaningful conversations with each other, learn from each other, and speak up for each other as well. 